\title{
A temporal switch in the insulin-signalling pathway that regulates hepatic IGF-binding protein-1 gene expression
}

\author{
David Finlay, Antonio J Ruiz-Alcaraz, Christopher Lipina, Stephane Perrier and \\ Calum Sutherland
}

Division of Pathology and Neurosciences, University of Dundee, Ninewells Hospital and Medical School, Dundee, Scotland, DD1 9SY, UK

(Requests for offprints should be addressed to C Sutherland; Email: c.d.sutherland@ dundee.ac.uk)

\begin{abstract}
Insulin regulation of hepatic gene transcription is a vital component of glucose homeostasis. Understanding the molecular regulation of this process aids the search for the defect(s) that promotes insulin-resistant states, such as diabetes mellitus. We have previously shown that the insulin regulation of hepatic IGF-binding protein-1 (IGFBP1) expression requires the signalling proteins phosphatidylinositol 3-kinase (PI 3-kinase) and mammalian target of rapamycin (mTOR). In this report, we demonstrate that activation of the mTOR pathway, without activation of its upstream regulator PI 3-kinase, reduces IGFBP1 expression. Therefore, mTOR activation is sufficient to mimic insulin regulation of this gene. However, longer exposure $(>3 \mathrm{~h}$ ) of cells to insulin reduces the importance of this pathway in insulin regulation of the gene, suggesting a temporal switch in signalling mechanisms linking insulin action to the IGFBP1 gene promoter. In contrast, the activation of PI 3-kinase is required for insulin regulation of IGFBP1 under all conditions tested. Therefore, an mTOR-independent, PI 3-kinasedependent pathway becomes more important in IGFBP1 regulation after long exposure to insulin. This is a novel concept in insulin regulation of gene expression and demonstrates the importance of temporal analysis of signalling processes.
\end{abstract}

Journal of Molecular Endocrinology (2006) 37, 227-237

\section{Introduction}

Increased serum insulin level following a meal results in complete shutdown of hepatic glucose output (Granner \& Pilkis 1990). This is achieved by turning off glycogen breakdown and endogenous gluconeogenesis (Pilkis \& Granner 1992, Nordlie \& Foster 1999). The latter process requires transcriptional repression of phosphoenolpyruvate carboxykinase (PEPCK) and glucose-6-phosphatase (G6Pase), ratelimiting steps in gluconeogenesis and loss of this regulation contributes to the hyperglycaemia that characterises type 2 diabetes mellitus (Granner \& Pilkis 1990, Granner \& O’Brien 1992, Kahn 1994, Hanson \& Reshef 1997, Sutherland et al. 2003). Much work is ongoing to understand the molecules and pathways that link the insulin receptor to these gene promoters. Indeed, an insulin-responsive DNA sequence, common to several gene promoters, including PEPCK and G6Pase, termed the PEPCK-like insulin receptor substrate (IRS) or the thymine-rich insulin-response element (TIRE), has been identified as the likely final target for this insulin-signalling cascade (for review, see O'Brien \& Granner 1996, Sutherland et al. 2003). Insulin signalling includes activation of the lipid kinase phosphatidylinositol 3-kinase (PI 3-kinase) to generate the second messenger phosphoinositide 3,4,5, trisphosphate (PIP3)
(Alessi \& Downes 1998, Cantley 2002), the stimulation of the nutrient sensing mammalian target of rapamycin (mTOR) pathway (Raught et al. 2001, Fisher \& White 2004), and a relatively weak induction of the Ras-p42/p44 mitogen-activated protein kinase (MAPK) pathway (Denton \& Tavare 1995). We and other researchers have demonstrated a requirement for PI 3-kinase in the regulation of most if not all of the TIRE-containing genes (Sutherland et al. 1995, Dickens et al. 1998, Durham et al. 1999). Other molecules that influence the rate of transcription of these genes include the transcription factors, FOXO (Guo et al. 1999, Schmoll et al. 2000, Puigserver et al. 2003), SREBP1c (Becard et al. 2001), PGC1 $\alpha$ (Puigserver et al. 2003), CBP (Zhou et al. 2004) and TORC2 (Koo et al. 2005), as well as the kinases protein kinase B (PKB) (Guo et al. 1999, Rena et al. 1999, Schmoll et al. 2000), glycogen synthase kinase-3 (GSK3; Lochhead et al. 2001) and mTOR (Band \& Posner 1997, Patel et al. 2002). However, evidence is accumulating that the exact sequence, context and positioning of the TIRE in a gene promoter affects which insulin-signalling pathways will regulate it (Hall \& Granner 1999, Patel et al. 2002, 2003, Gan et al. $2005 a, b)$. For example, glucocorticoids and glucagon induce, while insulin represses, PEPCK, G6Pase and IGF-binding protein-1 (IGFBP1) gene transcription, with the effects of insulin dominant over those of the 
other hormones (O'Brien \& Granner 1990, Unterman et al. 1991). All three of these gene promoters have related TIRE sequences, yet the regulation of IGFBP1 gene expression by insulin is the only one of these genes depend upon mTOR activation (Band \& Posner 1997, Patel et al. 2002). Indeed, although PI 3-kinase signalling appears critical in the regulation of most metabolic genes by insulin, only a handful of these (e.g. IGFBP1, HKII and insulin) are sensitive to rapamycin (Patel et al. 2002). The activation of mTOR stimulates phosphorylation and activation of the p70 S6 ribosomal protein kinase (S6K; Thomas \& Hall 1997, Dufner \& Thomas 1999) and eIF-4E BP1 (Hara et al. 1998, Beugnet et al. 2003). These processes are well known to modulate insulin regulation of protein synthesis (see, for review, Shigemitsu et al. 1999, Gingras et al. 2001), but there is less evidence linking them to transcriptional control. We have previously demonstrated that the overexpression of active S6K is not sufficient to regulate the rapamycin sensitive IGFBP1 TIRE, and that regulation of IGFBP1 gene expression in an S6K1 and S6K2 double knock out (KO) animal appears normal (Patel et al. 2002). This suggests that S6K activation may not link mTOR to this gene or is not sufficient to repress it. Therefore in this work, we assess whether activation of the pathway upstream of S6K, without PI 3-kinase induction, reduces IGFBP1 expression. In the process, we identify a novel temporal switch from the rapamycin-sensitive to a rapamycin-insensitive signalling pathway connecting the insulin receptor to the IGFBP1 gene promoter.

\section{Materials and methods}

\section{Materials}

$\left[\alpha^{32} \mathrm{P}\right]$ UTP and $\left[\gamma^{32} \mathrm{P}\right]$ ATP were obtained from Amersham. Insulin was purchased from Novo Nordisk (Crawley, West Sussex, UK), puromycin from Invitrogen, cycloheximide and dexamethasone from SigmaAldrich, rapamycin and LY294002 from Calbiochem (La Jolla, CA, USA) and the RNase Protection Assay Kit II from AMS Biotech/Ambion (Austin, TX, USA). All other chemicals were of the highest grade available.

\section{Cell culture}

The rat hepatoma cell line H4IIE was maintained in Dulbecco's modified Eagle's medium containing $1000 \mathrm{mg} / \mathrm{l}$ glucose, $5 \%(\mathrm{v} / \mathrm{v})$ foetal calf serum, as described previously (Forest et al. 1990). Cells were incubated with hormones, at $37^{\circ} \mathrm{C}$, for the times and at the concentrations indicated in the figures.

\section{RNA isolation and mRNA measurement}

H4IIE cells were serum starved overnight and treated with hormone/inhibitor for the times and at the concentrations indicated in the figures. Total cellular RNA was isolated using TriReagent (Sigma) following the manufacturer's instructions. An RNase protection assay was performed to determine the relative amounts of IGFBP 1 and cyclophilin mRNA in each sample (Patel et al. 2001). Band intensity was quantified on a phosphorimager (Fuji), data calculated as a ratio of IGFBP 1:cyclophilin mRNA and presented as percentage of IGFBP1 expression, where the intensity of control samples were set at $100 \%$. Alternatively, real-time PCR was used to quantify IGFBP1 and cyclophilin mRNA levels. Briefly, cDNA was synthesised using Superscript II Reverse Transciptase Kit (Invitrogen). PCR analysis was carried out in a model 7700 sequence detector (Applied Biosystems, Foster City, CA, USA) with primers and probes as follows: IGFBP1 5'-GCTGGATAGCTTCCACCTCATG-3' (sense), 5'-TCC ATTTCTTGAGGTCAGTGATCTC-3' (antisense) and $5^{\prime}$-CCCCATCCCGTGAGGACCAGC-3' ${ }^{\prime}$ (probe); cyclophilin $5^{\prime}$-TTACTAGGTCTGGCAGGAAGATTAAAG-3' (sense), $5^{\prime}$-CTGCATCTCTTGTCTCCAATGTG-3' (antisense) and 5'-AGAGGACCAAGGCGTTATCGAACTCC TTC-3' (probe).

Probes were synthesised with 5'-FAM (6-carboxyfluorescein) and $3^{\prime}$-TAMRA (6-carboxytetramethylrhodamine) modifications. IGFBP1 mRNA abundance is presented as a ratio to cyclophilin mRNA in the same sample.

\section{Preparation of cell extract}

H4IIE cells were incubated in serum-free medium with hormones and inhibitors for the times and at the concentrations indicated in the figures. Cells were then scraped into ice-cold lysis buffer $(25 \mathrm{mM}$ Tris- $\mathrm{HCl}(\mathrm{pH}$ $7 \cdot 4), 50 \mathrm{mM} \mathrm{NaF}, 100 \mathrm{mM} \mathrm{NaCl}, 1 \mathrm{mM}$ sodium vanadate, $5 \mathrm{mM}$ EGTA, $1 \mathrm{mM}$ EDTA, $1 \%$ (v/v) Triton $\mathrm{X}-100,10 \mathrm{mM}$ sodium pyrophosphate, $1 \mathrm{mM}$ benzamidine, $0 \cdot 1 \mathrm{mM}$ PMSF, $0 \cdot 27 \mathrm{M}$ sucrose and $0 \cdot 1 \%$ (v/v) 2-mercaptoethanol). Cell debris was removed by centrifugation at 13000 r.p.m. for $10 \mathrm{~min}$ and the protein concentration was determined by the method of Bradford, using BSA as an internal standard.

\section{Immunoprecipitation and assay of p70 S6 kinase}

Cell extracts $(0.5 \mathrm{mg})$ were incubated for $1 \mathrm{~h}$ on a shaking platform with protein G-Sepharose conjugated 
to $2 \cdot 5 \mu \mathrm{g}$ anti-p70 S6K antibody (Upstate, Lake Placid, NY, USA). The immunocomplexes were pelleted and washed with $1 \mathrm{ml}$ lysis buffer containing $0.5 \mathrm{M} \mathrm{NaCl}$, and twice with $1 \mathrm{ml}$ assay buffer $(25 \mathrm{mM}$ MOPS (pH 7.0), 0.4 mM EDTA, 0.1 M NaCl, 0.01\% Brij35 and $0.1 \%(\mathrm{v} / \mathrm{v})$ 2-mercaptoethanol). The immunoprecipitated p70 $\mathrm{S} 6 \mathrm{~K}$ was incubated at $30^{\circ} \mathrm{C}$ for $30 \mathrm{~min}$, in a total volume of $50 \mu \mathrm{l}$ containing $25 \mathrm{mM}$ MOPS $(\mathrm{pH}$ $7 \cdot 0), 0 \cdot 4 \mathrm{mM}$ EDTA, $0 \cdot 1 \mathrm{M} \mathrm{NaCl}, 0 \cdot 01 \%$ Brij35, $0 \cdot 1 \%$ (v/v) 2-mercaptoethanol, $10 \mathrm{mM} \mathrm{MgCl}, 0 \cdot 1 \mathrm{mM}$ $\left[\gamma^{32} \mathrm{P}\right]$ ATP $\left(0.5 \times 10^{6}\right.$ c.p.m. $\left./ \mathrm{nmol}\right)$ and $1 \mathrm{mM}$ Crosstide. A unit of kinase activity is defined as the amount which catalyses the phosphorylation of $1 \mathrm{nmol}$ substrate in $1 \mathrm{~h}$.

\section{Antibodies for western blot analysis}

Antibody to $\beta$-actin was purchased from Sigma-Aldrich, total GSK3 $\alpha / \beta$ from Upstate, while the phosphospecific Ser256 FOXO1, Ser9/Ser21 GSK3 $\alpha / \beta$, Thr308 PKB, Ser473 PKB, Thr202/Tyr204 p42/p44 MAPK and Ser235 S6 ribosomal protein antibodies were purchased from New England Biolabs (Hitchin, Hertfordshire, UK). H4IIE cell lysates were prepared following incubation with hormones as described in figures and analysed by western blot.

\section{Statistical analyses}

Student's $t$-tests were performed to establish significant differences between two groups, and 5\% confidence limits applied.

\section{Results and discussion}

\section{Cycloheximide activates the mTOR pathway inde- pendent of PI 3-kinase, and reduces the expression of IGFBP1}

Cycloheximide is a protein synthesis inhibitor (Siegal \& Sisler 1963) that is known to activate the hepatic mTORsignalling pathway in the absence of insulin (Kozma et al. 1989, Price et al. 1989). Therefore, we decided to use this agent to establish whether activation of the mTOR branch of the PI 3-kinase network was sufficient to repress the IGFBP1 gene. First, we characterised the effects of cycloheximide on the major insulin-signalling pathways in the H4IIE cell line (Fig. 1) in order to confirm the selective activation of this pathway. In these cells, mTOR signalling to ribosomal S6 kinase (as measured by phosphorylation of S6 ribosomal protein, Ser235) is activated by cycloheximide treatment (Fig. 1A). This occurs at concentrations similar to those that block protein synthesis (Beugnet et al. 2003), and increases in strength up to $35 \cdot 5 \mu \mathrm{M}(10 \mu \mathrm{g} / \mathrm{ml})$. However, exposure of cells to puromycin, a structurally distinct protein synthesis inhibitor (Fig. 1A) has no effect on mTOR activity, suggesting that the regulation of mTOR by cycloheximide is not related to general inhibition of protein synthesis. The activation of $\mathrm{mTOR}$ is sustained for at least $6.5 \mathrm{~h}$ (Fig. 1A), while the degree of induction of the pathway with $35.5 \mu \mathrm{M}$ cycloheximide, whether measured by S6 phosphorylation (Fig. 1B) or direct assay of S6K (Fig. 1C), is similar to that observed after insulin treatment. Importantly, cycloheximide induction of S6 phosphorylation or S6K activity is completely lost in the presence of $10 \mathrm{nM}$ rapamycin (Fig. $1 \mathrm{~B}$ and $\mathrm{C}$ ), thereby confirming the importance of mTOR to cycloheximide, as well as insulin, regulation of this pathway. Cycloheximide $(35.5 \mu \mathrm{M})$ weakly induces phosphorylation of PKB (Thr308/Ser473) as well as its downstream target GSK3, after 30-min treatment (Fig. 1B). These minor effects are insensitive to the presence of rapamycin, and are $<10 \%$ of the stimulation of this branch of the PI 3-kinase pathway by insulin (Fig. 1B). Meanwhile, no increase in phosphorylation of FOXO1, a transcriptional target of $\mathrm{PKB}$, is observed at any of the time points examined (Fig. 1B) suggesting that the PI 3-kinase-PKB pathway is probably not stimulated to a degree that initiates many (if any) downstream effects. Finally, cycloheximide strongly activates the p42/44 MAPK pathway to a far greater extent than obtained by insulin treatment, and this activation is insensitive to rapamycin (Fig. 1B). Again, this property of cycloheximide must be independent of protein synthesis inhibition since puromycin does not stimulate MAPK in the H4IIE cells (Fig. 1B). To our knowledge, this is the first demonstration that cycloheximide activates this growth-inducing pathway.

Cycloheximide $(35.5 \mu \mathrm{M})$ treatment of H4IIE cells for $3 \mathrm{~h}$ represses IGFBP1 gene expression (Fig. 2). This inhibition is seen on both basal (63.7\%, Fig. 2A) and glucocorticoid-induced (70.8\%, Fig. 2B) IGFBP1 expression. This indicates that activation of mTOR, without PI 3-kinase activation, mimics the effect of insulin on IGFBP1 expression. However, this repression is less dramatic than observed with insulin (90\%), consistent with the fact that insulin repression of IGFBP1 expression is not completely blocked by rapamycin (Patel et al. 2002). It should also be noted that we are measuring mRNA accumulation over a given time, therefore it is influenced by both the rate of transcription of the gene and the stability of the mRNA species. Cycloheximide has been reported to stabilise IGFBP1 mRNA (Ooi et al. 1993), therefore the true extent of transcriptional repression in response to mTOR activation by cycloheximide may be $>60-70 \%$ observed in our experiments. In contrast, insulin represses IGFBP1 mRNA predominantly through inhibition of transcription (Orlowski et al. 1991) and 


\section{A

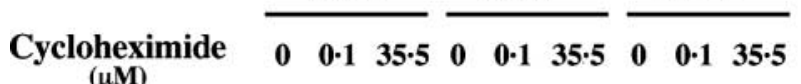

Phospho S6

ribosomal protei (Ser235)

$\beta$-Actin
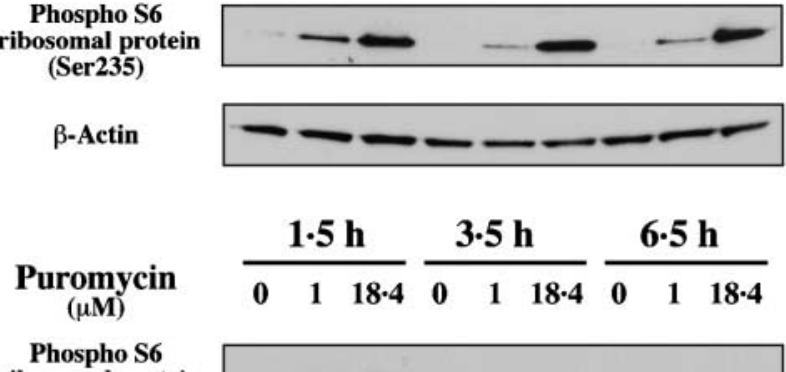

Phospho S6
ribosomal protein (Ser235)

$\beta$-Actin

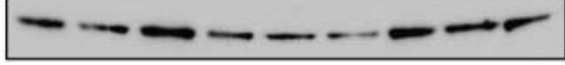

B

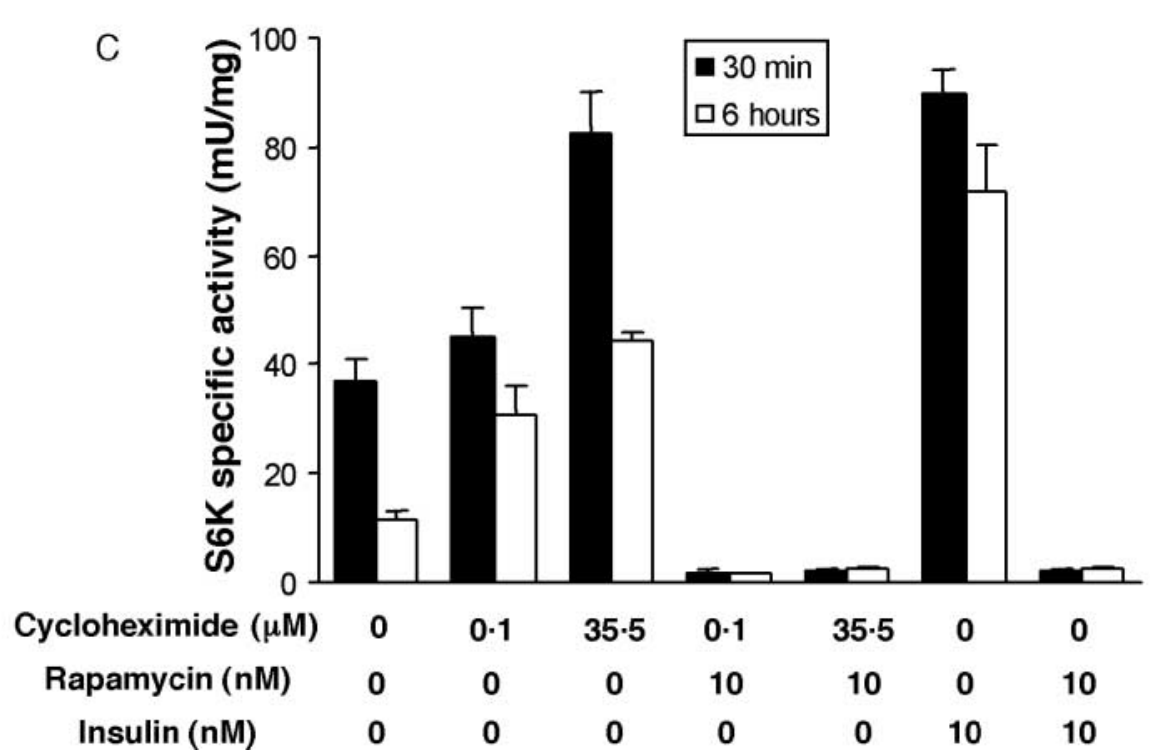

Figure 1 Effect of the protein synthesis inhibitors, cycloheximide and puromycin, on insulin signalling. H4IIE cells were serum starved overnight, prior to (A) incubation with cycloheximide $(0.1$ or $35.5 \mu \mathrm{M}$, which equates to $10 \mu \mathrm{g} / \mathrm{ml})$ or puromycin (1 or $18.4 \mu \mathrm{M}$, which equates to $10 \mu \mathrm{g} / \mathrm{ml})$ for $1.5,3.5$ or $6.5 \mathrm{~h}$, (B) preincubation for 30 min with or without cycloheximide $(10 \mu \mathrm{g} / \mathrm{ml})$ or puromycin $(10 \mu \mathrm{g} / \mathrm{ml})$ and then incubation with insulin $(10 \mathrm{nM})$, cycloheximide $(10 \mu \mathrm{g} / \mathrm{ml}) \pm$ rapamycin $(10 \mathrm{nM})$, or puromycin $(10 \mu \mathrm{g} / \mathrm{ml})$ for 0.5 , 3 or $6 \mathrm{~h} \mathrm{as} \mathrm{indicated} \mathrm{or}$ (C) preincubation for $30 \mathrm{~min}$ with or without cycloheximide $(10 \mu \mathrm{g} / \mathrm{ml})$ and then incubation with insulin $(10 \mathrm{nM})$, cycloheximide $(10 \mu \mathrm{g} / \mathrm{ml}) \pm \mathrm{rapamycin}(10 \mathrm{nM})$ for $0.5 \mathrm{or} 6 \mathrm{~h} \mathrm{as} \mathrm{indicated.}$ Cells were harvested and subjected to western blot analysis using primary antibodies as indicated (B) or S6K activity measured as described in Materials and methods (C). 
A

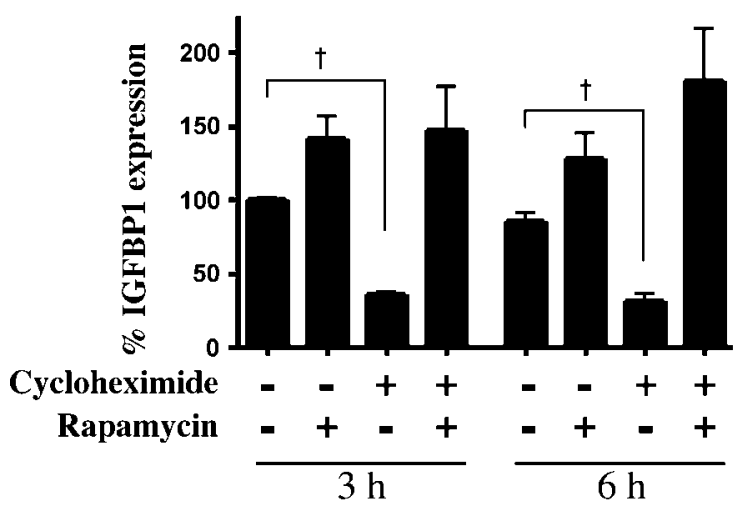

B

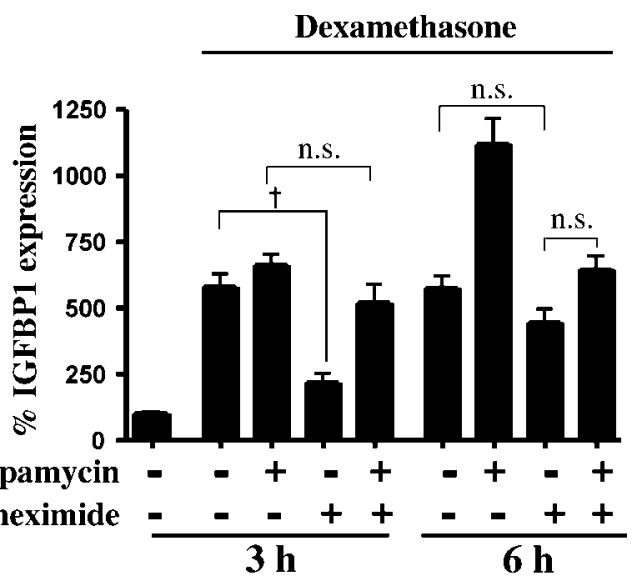

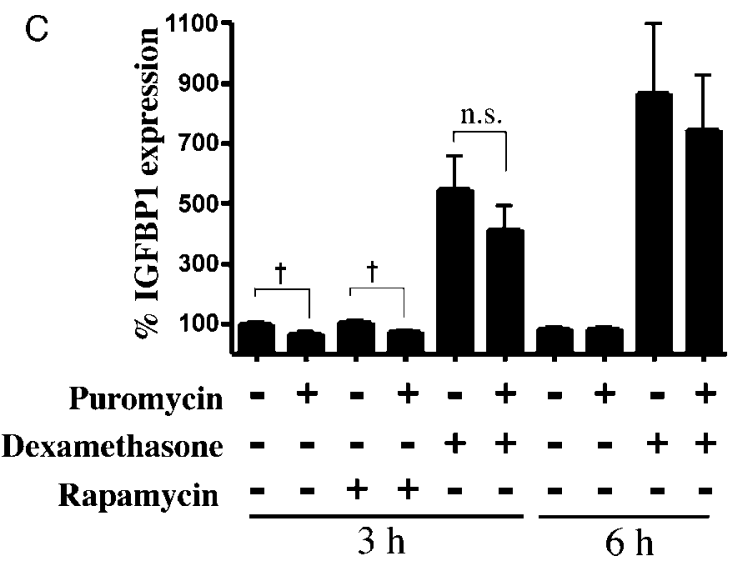

Figure 2 Cycloheximide treatment inhibits IGFBP1 gene expression. H4IIE cells were serum starved overnight prior to a 30 min preincubation with or without cycloheximide $(10 \mu \mathrm{g} / \mathrm{ml})$. Cells were then incubated \pm cycloheximide $(10 \mu \mathrm{g} / \mathrm{ml}) \pm \mathrm{rapamycin}$ $(10 \mathrm{nM})$ in the $(A)$ absence or $(B)$ presence of dexamethasone $(500 \mathrm{nM})$ for the times indicated. (C) Alternatively, cells were serum starved overnight prior to a $30 \mathrm{~min}$ preincubation with or without puromycin $(10 \mu \mathrm{g} / \mathrm{ml})$ followed by incubation \pm puromycin $(10 \mu \mathrm{g} / \mathrm{ml}) \pm$ rapamycin $(10 \mathrm{nM}) \pm$ dexamethasone $(500 \mathrm{nM})$ as indicated for 3 and $6 \mathrm{~h}$. The cells were harvested, total RNA isolated and an RNase protection assay (RPA) performed to determine the levels of IGFBP1 mRNA. Results are presented as the mean \pm S.E.M. of at least four experiments. ${ }^{\star} P<0.01 ;{ }^{\dagger} P<0.001 ;$ n.s., not significant.

does not affect the stability of mRNA (Unterman et al. 1991). Following $6 \mathrm{~h}$ incubation with cycloheximide basal IGFBP1 expression is still reduced compared to control, however, the effect of this agent is lost in the glucocorticoid-stimulated $6 \mathrm{~h}$ incubation (Fig. 2B). It is possible that the effects of cycloheximide on mRNA stability are more apparent in the longer incubations in the presence of glucocorticoid, thereby masking any gene repression. Equally, the loss of cycloheximide repression at the longer time points could be due to its effects on protein synthesis, reducing the level of a key transcription factor.

In the studies demonstrating stabilisation of IGFBP1 mRNA by cycloheximide, it was also noted that this agent inhibits basal transcription of the IGFBP1 gene (Ooi et al. 1993). This was assumed to be due to the inhibition of protein synthesis. However, we find that an alternative protein synthesis inhibitor, puromycin, which does not effect mTOR signalling (Fig. 1B), has a much small repressive effect $(32 \cdot 1 \%)$ on basal IGFBP1 gene expression (Fig. 2C). This small effect of puromycin is not observed on dexamethasone-induced IGFBP1 expression levels (Fig. 2C), but is similar to a reported slight decrease in IGFBP1 expression with a third protein synthesis inhibitor, anisomycin (Ooi et al. 1993). Therefore, it appears that the inhibition of protein synthesis can slightly reduce the rate of basal IGFBP1 transcription, but that an additional mechanism is invoked in the presence of cycloheximide. We hypothesised that this second mechanism requires the activation of the mTOR pathway (Fig. 1). 
A

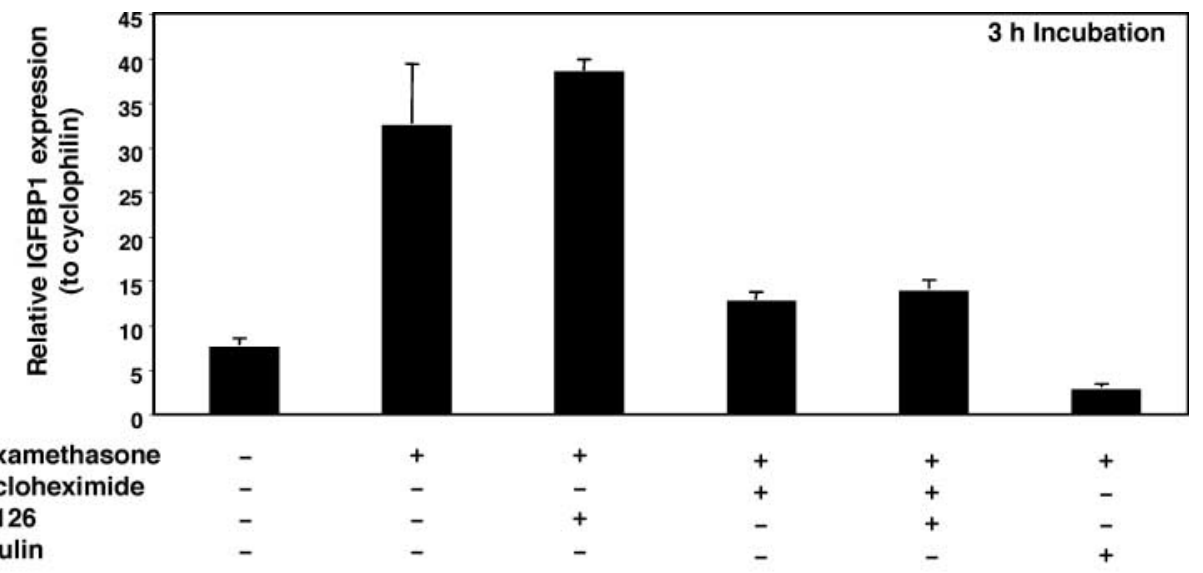

B

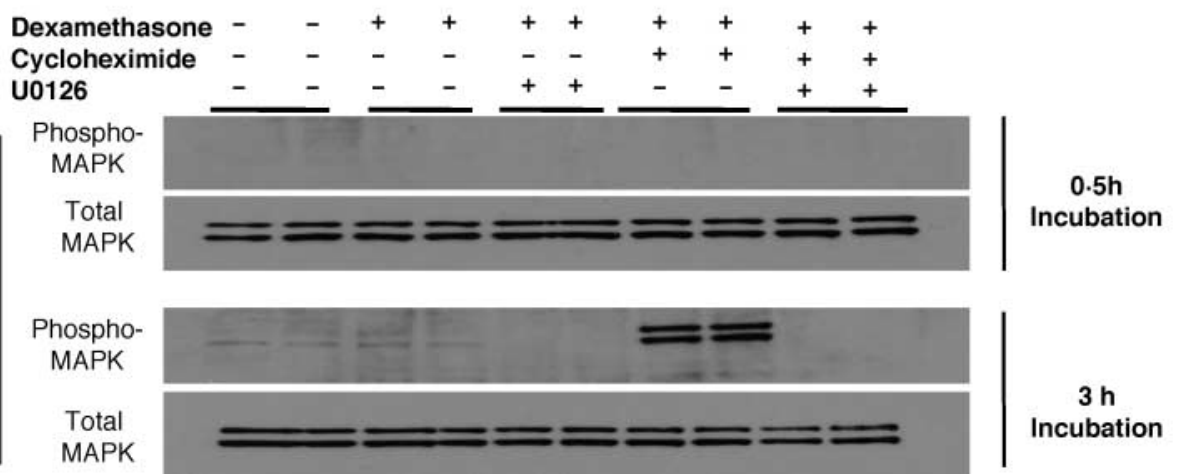

Figure 3 Cycloheximide inhibition of IGFBP1 gene expression does not require activation of p42/44 MAPK. $\mathrm{H} 4 \mathrm{IIE}$ cells were serum starved overnight prior to incubation \pm cycloheximide $(10 \mu \mathrm{g} / \mathrm{ml}) \pm \mathrm{U} 0126(10 \mu \mathrm{M})$ in the presence of dexamethasone $(500 \mathrm{nM}) \pm$ insulin $(10 \mathrm{nM})$ for the times indicated. Cells treated with U0126 had also a 30 min preincubation with this inhibitor. The cells were harvested, and total RNA isolated and Taqman analysis performed to determine the levels of (A) IGFBP1 mRNA or (B) western blot analysis performed to assess MAPK activation. Results in (A) are presented as the mean \pm S.E.M. of three experiments assayed in triplicate, while $(B)$ is a representative experiment of two separate analysis.

\section{The major repressive effect of cycloheximide requires mTOR activity}

The repression of basal or induced IGFBP1 gene expression by cycloheximide is inhibited by rapamycin, confirming the importance of mTOR activity in this effect of cycloheximide (Fig. 2). Also rapamycin completely blocks the action of cycloheximide, in contrast to its partial effect on insulin repression. Importantly, in a parallel analysis, cycloheximide was found to have no repressive effect on G6Pase expression (data not shown). This gene is repressed by insulin, independent of mTOR activation but dependent on PI 3-kinase activation (Dickens et al. 1998, Patel et al. 2002). As expected, the small effect of puromycin on IGFBP1 expression is not affected by rapamycin (Fig. 2C). Since cycloheximide also activates p42/p44 MAPK in these cells (Fig. 1), and this pathway has recently been linked to the regulation of IGFBP1 expression (Gan et al. $2005 b$ ), it was important to rule out this pathway in the actions of cycloheximide on the IGFBP1 gene. U0126, a relatively specific inhibitor of p42/44 MAPK activation, has no effect on the ability of cycloheximide to regulate IGFBP1 expression (Fig. 3A), yet completely inhibits cycloheximide induction of the p42/44 MAPK (Fig. 3B). Similarly, a structurally unrelated p42/44 MAPK inhibitor, PD98059, has no effect on cycloheximide repression of IGFBP1 gene expression (data not shown). Therefore, the cycloheximide regulation of IGFBP1 expression requires the mTOR pathway and not $\mathrm{p} 42 / 44$ MAPK activation. We have previously found that sustained activation of S6K1 is not sufficient to repress the IGFBP1 TIRE (Patel et al. 2002). This suggests that an alternative downstream component of mTOR signalling links it to the IGFBP1 gene promoter. Yeast contains an mTOR homologue (Tor), but not any S6K activity (Raught et al. 2001). Potential yeast proteins downstream of Tor, include Msn2p, Msn4p, Gln3p, Tap42p, Mks1p, Ure2p and Gat1p (Beck \& Hall 1999; Chan et al. 2000, Schmelzle \& Hall 2000, Shamji et al. 2000). 
Whether mammalian equivalents of these proteins, or other as yet unidentified mTOR targets, mediate mTOR regulation of IGFBP1 remains to be established. Meanwhile, it is known that inhibitors of GSK3 repress IGFBP1 gene expression (Finlay et al. 2004). There is a slight increase in GSK3 $\alpha / \beta$ phosphorylation at inhibitory regulatory sites (Ser21/Ser9 respectively; Sutherland et al. 1993, Sutherland \& Cohen 1994) in response to cycloheximide (Fig. 1B). However, the phosphorylation of GSK3 was not sensitive to rapamycin (Fig. 1B), and the relatively weak phosphorylation (in comparison to insulin, which inhibits GSK3 approximately $50 \%$ in these cells; Lochhead et al. 2001) dictates that inhibition of GSK3 is $<25 \%$. Taken together with the lack of effect of rapamycin, it seems highly unlikely that GSK3 inhibition mediates the effects of cycloheximide on IGFBP1 expression.

\section{Time-dependent effects of rapamycin on insulin regulation of IGFBP1 expression}

Insulin stimulation of H4IIE cells results in activation of mTOR and downstream signalling, as judged by increased phosphorylation at Ser235 of S6 ribosomal protein (Fig. 4) and S6K activity (Fig. 1C). Ten nanomolar of rapamycin is sufficient to completely block insulin-induced mTOR signalling between 0.5 and $6 \mathrm{~h}$, and actually reduces mTOR activity below basal levels (Figs 1C and 4A). Full induction of mTOR signalling by insulin is maintained (and remains rapamycin sensitive) for at least $15 \mathrm{~h}$ following stimulation (Fig. 4B). In contrast, insulin-stimulated phosphorylation of PKB (Thr308) or GSK3 (Ser21/9) is insensitive to the presence of $10 \mathrm{nM}$ rapamycin (Fig. 4B). Insulin inhibition of both basal- and dexamethasone-induced IGFBP1 expression is partially reduced when cells are incubated with rapamycin for $3 \mathrm{~h}$ (Fig. 5). Surprisingly, the effect of rapamycin on the regulation of the gene decreases substantially in cells incubated for longer periods with insulin (Fig. 5). This loss of rapamycin sensitivity with time is more pronounced when the gene is first induced using glucocorticoid (Fig. 5B vs 5A). That is, insulin repression of IGFBP1 is blocked by $\sim 50 \%$ if measured after $3 \mathrm{~h}$ incubation with rapamycin, but $\sim 30 \%$ after $6 \mathrm{~h}$ incubation and only $\sim 15 \%$ after $15 \mathrm{~h}$ incubation (Fig. 5B, lower panel). This is despite the inhibition of mTOR signalling by rapamycin being maintained across the full $15 \mathrm{~h}$ treatment (Fig. 4). The decrease in the rapamycin block of insulin repression of basal expression is less pronounced but the trend is similar (Fig. 5A, lower panel).

Insulin repression of IGFBP1 is dependent on PI 3-kinase activity (Fig. 6). Since rapamycin sensitivity of the IGFBP1 gene promoter decreases with time (Fig. 5), we
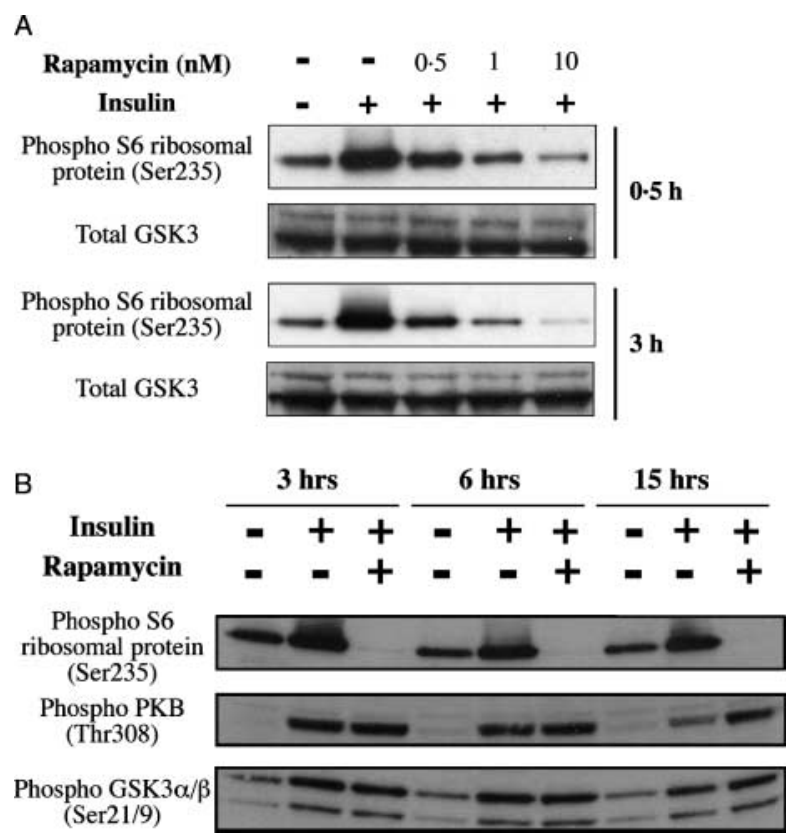

Figure 4 Effect of rapamycin on insulin signalling. H4IIE cells were starved overnight prior to incubation \pm insulin $(10 \mathrm{nM}) \pm$ rapamycin $(0.5-10 \mathrm{nM})$ for $(\mathrm{A}) 0.5$ and $3 \mathrm{~h}$ or $(\mathrm{B}) 3,6$ and $15 \mathrm{~h}$ (10 nM rapamycin) as indicated. Cells were harvested and subjected to western blot analysis probing with antibodies as indicated. Similar results were obtained for two such experiments.

next examined the requirement for PI 3-kinase activity over the same incubation period. Insulin repression of basal (Fig. 6A) and induced (Fig. 6B) IGFBP1 is completely blocked by LY294002 $(100 \mu \mathrm{M})$, a selective inhibitor of PI 3-kinase (Vlahos et al. 1994), at all time points examined. LY294002 increases IGFBP1 expression in H4IIE cells, suggesting some basal PI 3-kinase activity in this immortal cell line. This agent blocks insulin action of the mTOR pathway as well as activation of PKB (Alessi \& Downes 1998). Therefore, the requirement for PI 3-kinase signalling for insulin repression of IGFBP1 expression is maintained. This result may explain previous reports that rapamycin has little effect on insulin repression of IGFBP1 expression, where mRNA levels were examined in relatively long incubations (Cichy et al. 1998). We have previously found that insulin repression of the isolated IGFBP1 TIRE is completely blocked in the presence of rapamycin (Patel et al. 2002). In those experiments, the effect of rapamycin on the isolated TIRE was measured following transient transfection of a TIRE-luciferase reporter construct, and the rapamycin sensitivity of this construct is apparent even after $18 \mathrm{~h}$ stimulation. This difference between isolated element and intact promoter suggests that additional insulinresponse elements are present in the complete IGFBP1 gene promoter. The altered signalling may reflect a 
A
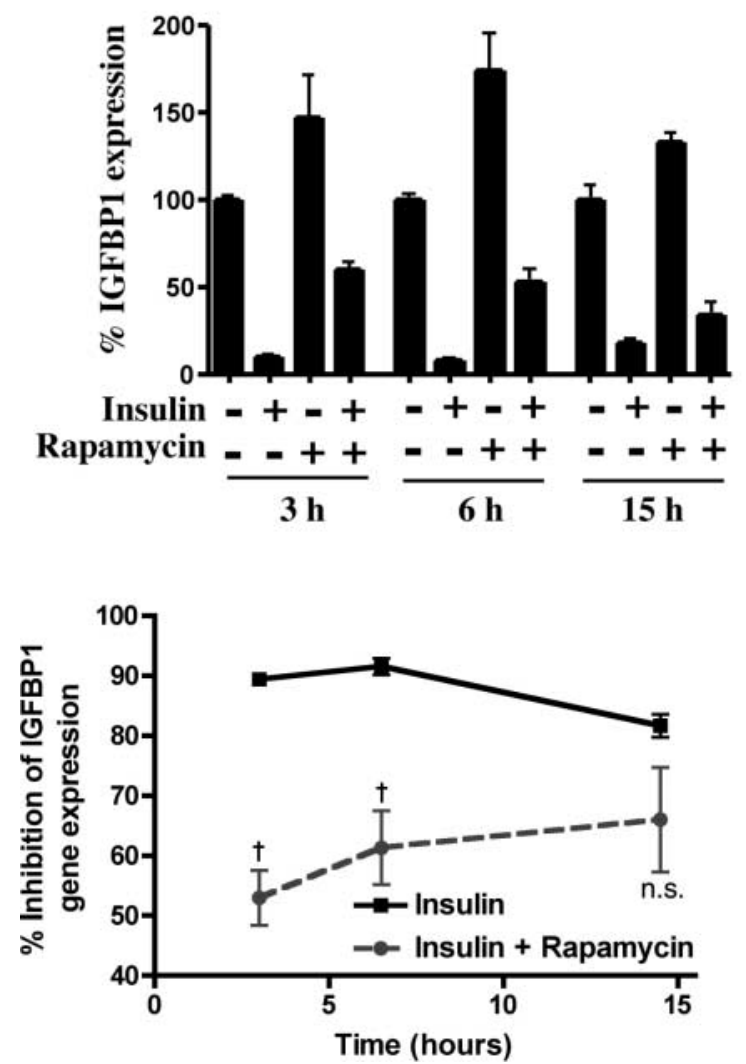

B
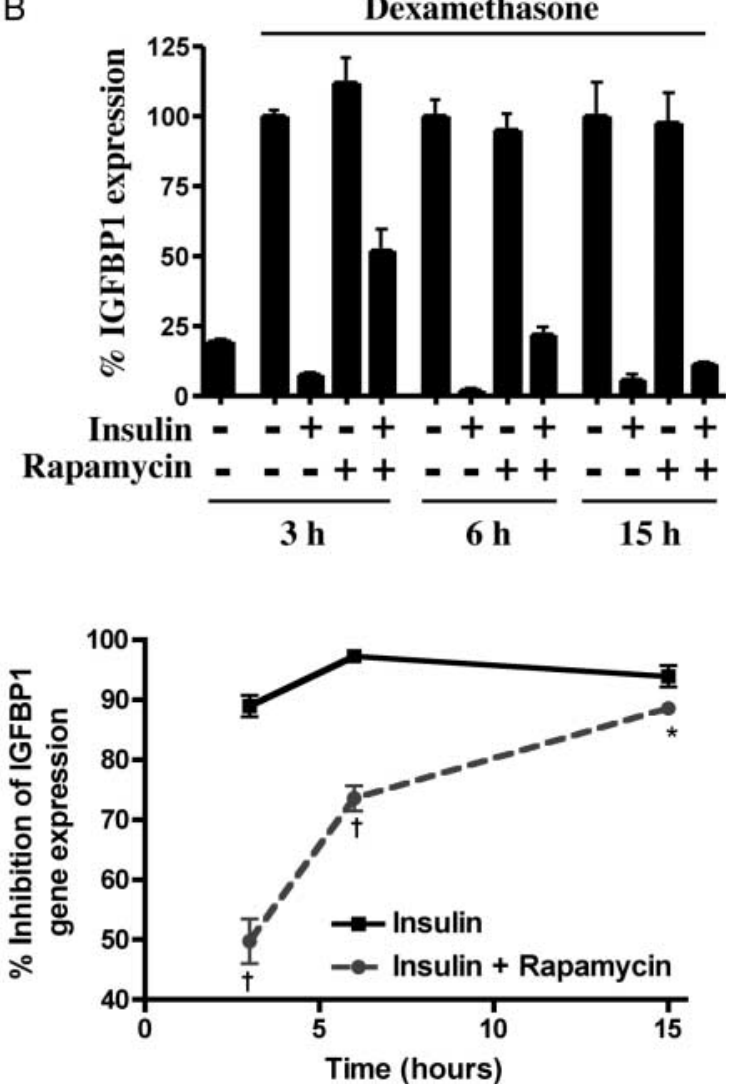

Figure 5 Time-dependent mTOR regulation of IGFBP1 gene expression. H4IIE were starved overnight prior to incubation \pm insulin $(10 \mathrm{nM})$, \pm rapamycin $(10 \mathrm{nM})$ in the absence $(A)$ or presence $(B)$ of dexamethasone $(500 \mathrm{nM})$ for 3,6 and $15 \mathrm{~h}$. Cells were harvested, total RNA isolated and an RPA performed to determine IGFBP1 mRNA concentration. Results are presented as the mean \pm S.E.M. of at least four separate experiments (upper panels). The data are also presented as line graphs illustrating the percentage of insulin inhibition of IGFBP1 expression \pm rapamycin treatment (lower panels). ${ }^{\star} P<0 \cdot 05 ;{ }^{\dagger} P<0 \cdot 001$; n.s., not significant.

temporal switch in the insulin-response element mediating the repression of IGFBP1. Unterman and colleagues have recently reported distinct transcriptional complexes involved in insulin repression of this promoter (Gan et al. 2005a), although the identity of the novel DNA sequence is not yet elucidated. A timedependent difference in rapamycin sensitivity of such complexes awaits further characterisation of these regulatory elements.

\section{Summary}

We show for the first time that activation of the mTOR pathway is sufficient to reduce IGFBP1 expression, although the effect is not as complete as observed with insulin. Therefore, this pathway acts in an additive manner with another PI 3-kinase-dependent pathway to completely repress this gene promoter. In addition, we demonstrate that the signalling pathway to the IGFBP1 gene promoter alters with the duration of stimulation. That is, the requirement for the mTOR component of the regulation declines with insulin exposure length (Fig. 7). We suggest that this may be a novel paradigm in insulin signalling and other rapamycin-sensitive actions of insulin require further study. Insulin resistance is thought to occur through reduced signalling capacity in one or more signalling pathways (Shulman 2000). Indeed, both the mTOR and PI 3-kinase pathways are implicated in reduced insulin action in muscle, fat and liver cells (Shulman 2000). The importance of the switch between mTOR-dependent and -independent pathways in insulin action is not clear. In the simplest scenario, loss of mTOR signalling but not PI 3-kinase signalling would delay insulin repression of IGFBP1 expression, while reduced PI 3-kinase signalling would have a more prolonged effect on this gene. Therefore, IGFBP1 gene expression may be a biomarker that would allow delineation of the signalling defect in an insulin-resistant subject. 
A
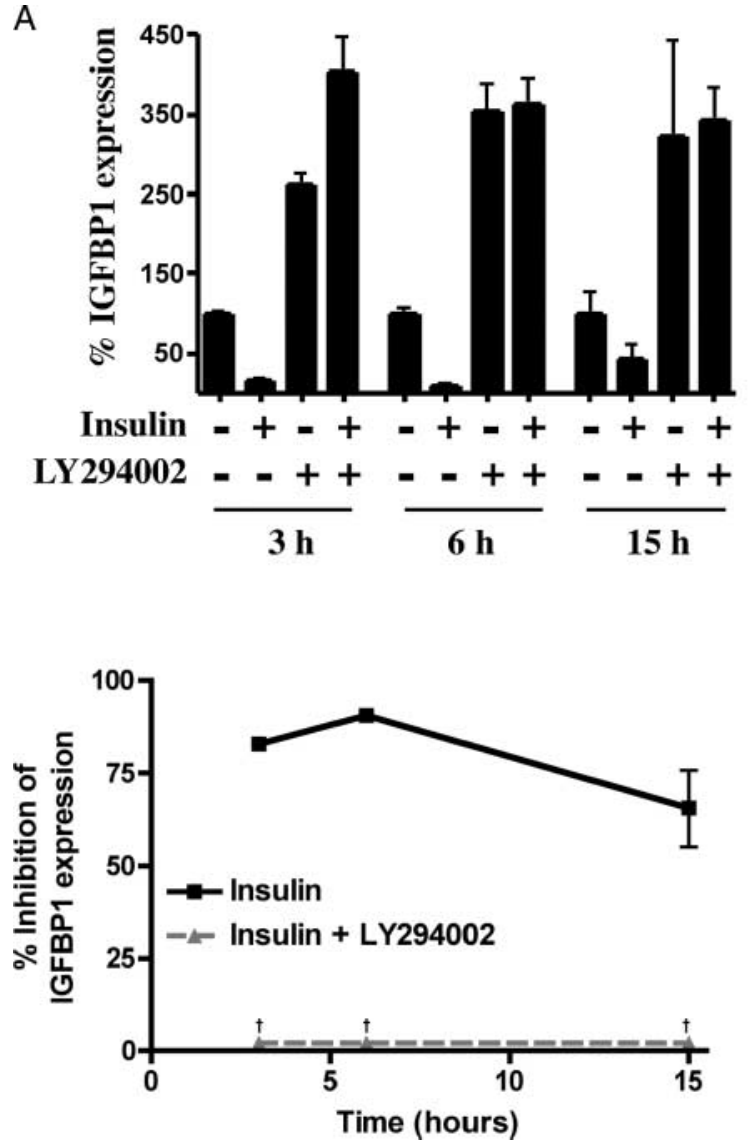

B
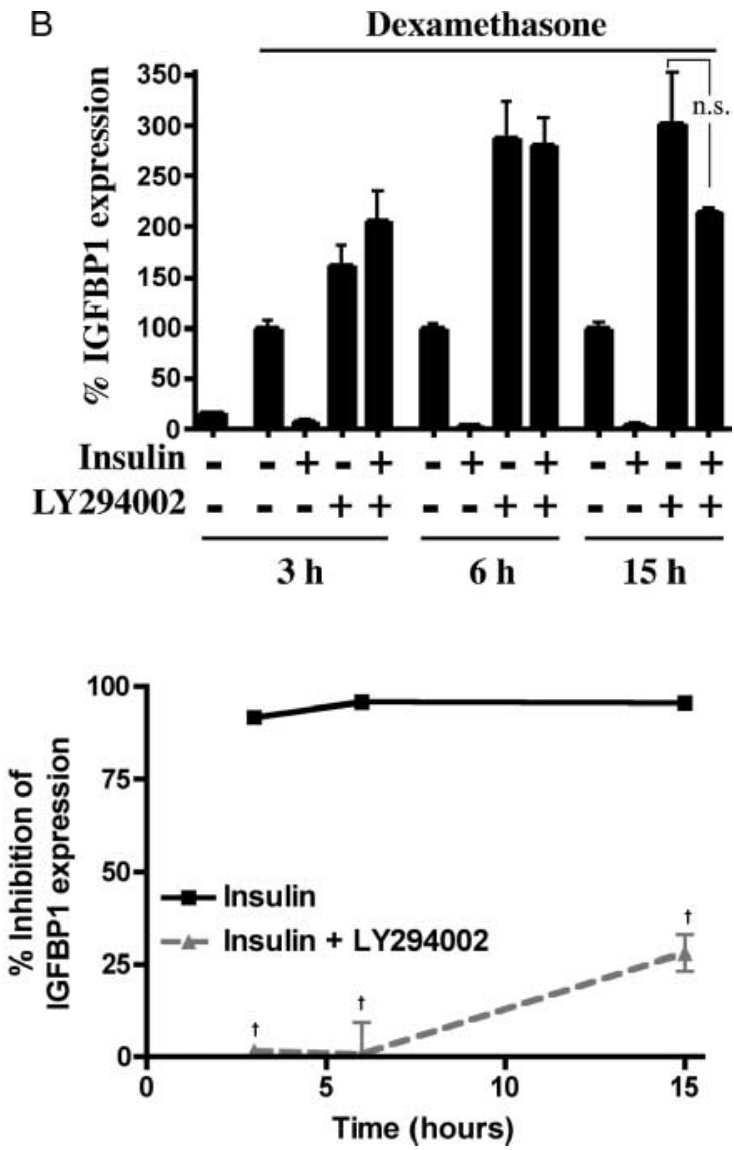

Figure 6 Insulin inhibition of IGFBP1 gene expression is PI 3-kinase dependent. H4IIE were starved overnight prior to incubation \pm insulin (10 nM), \pm LY294002 (100 $\mu \mathrm{M})$ in the (A) absence or (B) presence of dexamethasone $(500 \mathrm{nM})$ for 3,6 and $15 \mathrm{~h}$. Cells were harvested, total RNA isolated and an RPA performed to determine IGFBP1 mRNA concentration. Results are presented as the mean \pm S.E.M. of at least four separate experiments (upper panels). The data are also presented as line graphs illustrating the percentage of insulin inhibition of IGFBP1 expression \pm LY294002 treatment (lower panels). ${ }^{\dagger} P<0 \cdot 001 ;$ n.s., not significant.

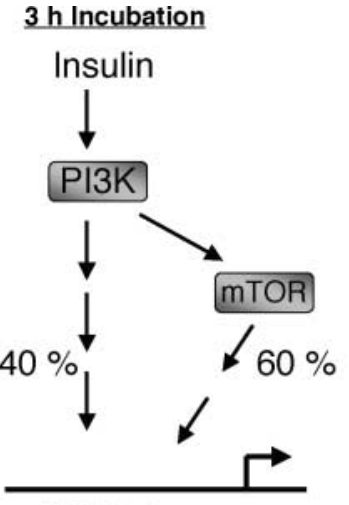

IGFBP1 Promoter

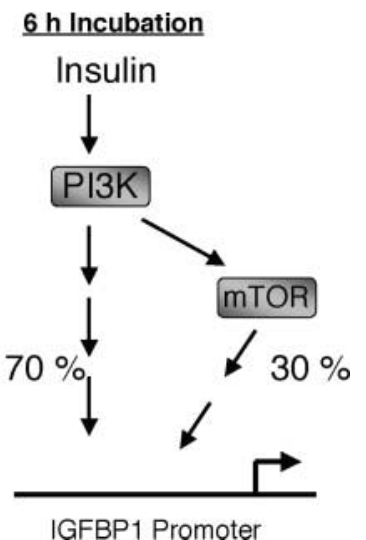

IGFBP1 Promoter

Figure 7 Model of temporal switching of signalling pathways mediating insulin inhibition of IGFBP1 gene expression. The relative contribution of the rapamycin-sensitive and insensitive pathways alters between 3 and $6 \mathrm{~h}$ incubation with insulin. This may reflect the slow onset of an mTOR-independent signalling pathway or a change in the transcriptional complex mediating the repression in response to insulin.

\section{Acknowledgements}

This work was supported by the Diabetes UK Senior Fellowship (02/0002473). The authors declare that there is no conflict of interest that would prejudice the impartiality of this scientific work.

\section{References}

Alessi DR \& Downes CP 1998 The role of PI 3-kinase in insulin action. Biochimica et Biophysica Acta 1436 151-164.

Band CJ \& Posner BI 1997 PI 3-kinase and p70S6 kinase are required for insulin but not bisperoxovanadium 1,10-phenanthroline inhibition of IGFBP gene expression. Journal of Biological Chemistry 272 138-145.

Becard D, Hainault I, Azzout-Marniche D, Bertry-Coussot L, Ferre P \& Foufelle F 2001 Adenovirus-mediated overexpression of sterol regulatory element binding protein-1c mimics insulin effects on hepatic gene expression and glucose homeostasis in diabetic mice. Diabetes 50 2425-2430. 
Beck T \& Hall MN 1999 The TOR signalling pathway controls nuclear localisation of nutrient-regulated transcription factors. Nature $\mathbf{4 0 2}$ 689-692.

Beugnet A, Tee AR, Taylor PM \& Proud CG 2003 Regulation of targets of mTOR (mammalian target of rapamycin) signalling by intracellular amino acid availability. Biochemical Journal 372 555-566. Cantley LC 2002 The PI 3-kinase pathway. Science 296 1655-1657.

Chan T-F, Carvalho J, Riles L \& Zheng XFS 2000 A chemical genomics approach toward understanding the global functions of the target of rapamycin protein (TOR). PNAS 97 13227-13232.

Cichy SB, Uddin S, Danilkovitch A, Guo S, Klippel A \& Unterman TG 1998 PKB mediates effects of insulin on hepatic IGFBP1 gene expression through a conserved insulin response sequence. Journal of Biological Chemistry 273 6482-6487.

Denton RM \& Tavare JM 1995 Does mitogen-activated-protein kinase have a role in insulin action? The cases for and against European Journal of Biochemistry 227 597-611.

Dickens M, Svitek CA, Culbert AA, O’Brien RM \& Tavare JM 1998 Central role for PI 3-kinase in the repression of glucose-6phosphatase gene transcription by insulin. Journal of Biological Chemistry 273 20144-20149.

Dufner A \& Thomas G 1999 Ribosomal S6 kinase signaling and control of translation. Experimental Cell Research 253 100-109.

Durham SK, Suwanichkul A, Scheimann AO, Yee D, Jackson JG, Barr FG \& Powell DR 1999 FKHR binds the insulin response element in the insulin-like growth factor binding protein-1 promoter. Endocrinology $1403140-3146$.

Finlay D, Patel S, Dickson LM, Shpiro N, Marquez R, Rhodes CJ \& Sutherland C 2004 Glycogen synthase kinase-3 regulates IGFBP-1 gene transcription through the thymine-rich insulin response element: inhibition is required for full regulation of this promoter element by insulin. BMC Molecular Biolology 515.

Fisher TL \& White MF 2004 Signaling pathways: the benefits of good communication. Current Biology 14 R1005-R1007.

Forest CD, O'Brien RM, Lucas PC, Magnuson MA \& Granner DK 1990 Regulation of PEPCK gene expression by insulin. Use of the stable transfection approach to locate an insulin responsive sequence. Molecular Endocrinology 4 1302-1310.

Gan L, Han Y, Bastianetto S, Dumont Y, Unterman TG \& Quirion R $2005 a$ FoxO-dependent and -independent mechanisms mediate SirT1 effects on IGFBP-1 gene expression. Biochemical and Biophysical Research Communications 337 1092-1096.

Gan L, Pan H \& Unterman TG $2005 b$ Insulin response sequencedependent and -independent mechanisms mediate effects of insulin on glucocorticoid-stimulated insulin-like growth factor binding protein-1 promoter activity. Endocrinology 146 4274-4280.

Gingras A-C, Raught B \& Sonenberg N 2001 Regulation of translation initiation by FRAP/mTOR. Genes and Development 15 807-826.

Granner DK \& Pilkis S 1990 The genes of hepatic glucose metabolism. Journal of Biological Chemistry 265 10173-10178.

Granner DK \& O'Brien RM 1992 Molecular physiology and genetics of NIDDM. Diabetes Care 15 369-395.

Guo S, Rena G, Cichy S, He X, Cohen P \& Unterman TG 1999 Phosphorylation of Ser 256 by PKB disrupts transactivation by FKHR and mediates effects of insulin on IGFBP-1 promoter activity through a conserved insulin response sequence. Journal of Biological Chemistry 274 17184-17192.

Hall RK \& Granner DG 1999 Insulin regulates expression of metabolic genes through divergent signaling pathways. Journal of Basic and Clinical Physiology and Pharmacology 10 119-133.

Hanson RW \& Reshef L 1997 Regulation of PEPCK gene expression. Annual Review of Biochemistry 66 581-611.

Hara K, Yonezawa K, Weng QP, Kozlowski MT, Belham C \& Avruch J 1998 Amino acid sufficiency and mTOR regulate p70 S6 kinase and eIF-4E BP1 through a common effector mechanism. Journal of Biological Chemistry 273 14484-14494.

Kahn CR 1994 Insulin action, diabetogenes and the cause of type II diabetes. Diabetes 43 1066-1084.
Koo SH, Flechner L, Qi L, Zhang X, Screaton RA, Jeffries S, Hedrick S, $\mathrm{Xu}$ W, Boussouar F, Brindle P et al. 2005 The CREB coactivator TORC2 is a key regulator of fasting glucose metabolism. Nature $\mathbf{4 3 7}$ 1109-1111.

Kozma S, Lane HA, Ferrari S, Luther H, Siegmann M \& Thomas G 1989 A stimulated $\mathbf{S} 6$ kinase from rat liver: identity with the mitogen activated S6 kinase of 3T3 cells. EMBO Journal 8 412-4132.

Lochhead PA, Coghlan MP, Rice SQJ \& Sutherland C 2001 Inhibition of GSK3 selectively reduces G6Pase and PEPCK gene expression. Diabetes 50 937-947.

Nordlie RC \& Foster JD 1999 Regulation of glucose production by the liver. Annual Review of Nutrition 19 379-406.

O'Brien RM \& Granner DK 1990 PEPCK gene as a model of inhibitory effects of insulin on gene transcription. Diabetes Care 13 327-339.

O’Brien RM \& Granner DK 1996 Regulation of gene expression by insulin. Physiological Reviews 76 1109-1161.

Ooi GK, Brown DR, Suh D-S, Tseng LY-H \& Rechler MM 1993 Cycloheximide stabilises IGFBP-1 mRNA and inhibits IGFBP-1 transcription in H4IIE cells. Journal of Biological Chemistry 268 16664-16672.

Orlowski CC, Ooi GT, Brown DR, Yang YW, Tseng LY \& Rechler MM 1991 Insulin rapidly inhibits insulin-like growth factor-binding protein-1 gene expression in H4-II-E rat hepatoma cells. Molecular Endocrinology 5 1180-1187.

Patel S, Lochhead PA, Rena G \& Sutherland C 2001 Antagonistic effects of phorbol esters on insulin regulation of IGFBP-1 but not glucose-6-phosphatase gene expression. Biochemical Journal $\mathbf{3 5 9}$ 611-619.

Patel S, Lochhead PA, Rena G, Fumagalli S, Pende M, Kozma S, Thomas GM \& Sutherland C 2002 Insulin regulation of IGF-binding protein-1 gene expression is dependent on mammalian target of rapamycin (mTOR), but independent of S6K activity. Journal of Biological Chemistry 277 9889-9895.

Patel S, Lipina C \& Sutherland C 2003 Different mechanisms are used by insulin to repress three genes that contain a homologous thymine-rich insulin response element. FEBS Letters $\mathbf{5 4 9} 72-76$.

Pilkis SJ \& Granner DK 1992 Molecular physiology of the regulation of hepatic gluconeogenesis and glycolysis. Annual Review of Physiology 54 885-909.

Price DJ, Nemenoff RA \& Avruch J 1989 Purification of a hepatic S6 kinase from cycloheximide-treated rats. Journal of Biological Chemistry 264 13825-13833.

Puigserver P, Rhee J, Donovan J, Walkey CJ, Yoon JC, Oriente F, Kitamura Y, Altomonte J, Dong H, Accili D et al. 2003 Insulinregulated hepatic gluconeogenesis through FOXO1-PGC-1alpha interaction. Nature 423 550-555.

Raught B, Gingras A-C \& Sonenberg N 2001 The target of rapamycin (TOR) proteins. PNAS 98 7037-7044.

Rena G, Guo S, Cichy SC, Unterman TG \& Cohen P 1999 Phosphorylation of the transcription factor forkhead family member FKHR by PKB. Journal of Biological Chemistry 274 17179-17183.

Schmelzle T \& Hall MN 2000 TOR, a central controller of cell growth. Cell 103 253-262.

Schmoll D, Walker KS, Alessi DR, Grempler R, Burchell A, Guo S, Walther R \& Unterman TG 2000 Regulation of glucose-6phosphatase gene expression by protein kinase $\mathrm{B}$ (alpha) and the forkhead transcription factor FKHR. Journal of Biological Chemistry 275 36324-36333.

Shamji AF, Kuruvilla FG \& Schreiber SL 2000 Partitioning the transcriptional program induced by rapamycin among the effectors of the Tor proteins. Current Biology 10 1574-1581.

Shigemitsu K, Tsujishita Y, Hara K, Nanahoshi M, Avruch J \& Yonezawa K 1999 Regulation of translational effectors by amino acid and mammalian target of rapamycin signaling pathways. Journal of Biological Chemistry 274 1058-1065.

Shulman GI 2000 Cellular mechanisms of insulin resistance. Journal of Clinical Investigation 106 171-176. 
Siegal MR \& Sisler HD 1963 Inhibition of protein synthesis in vitro by cycloheximide. Nature 200 675-676.

Sutherland C \& Cohen P 1994 The $\alpha$-isoform of glycogen synthase kinase-3 from rabbit skeletal muscle is inactivated by p70 56 kinase or MAP kinase-activated protein kinase-1 in vitro. FEBS Letters 338 37-42.

Sutherland C, Leighton IA \& Cohen P 1993 Inactivation of glycogen synthase kinase- $3 \beta$ by phosphorylation; new kinase connections in insulin and growth factor signalling. Biochemical Journal 296 15-19.

Sutherland C, O’Brien RM \& Granner DK 1995 Phosphatidylinositol 3-kinase, but not $\mathrm{p} 70 / \mathrm{p} 85$ ribosomal $\mathrm{S} 6$ protein kinase, is required for the regulation of Phosphoenolpyruvate Carboxykinase gene expression by insulin. Journal of Biological Chemistry 270 15501-15506.

Sutherland C, O'Brien RM \& Granner DK 2003 Genetic regulation of glucose metabolism. In Handbook of Physiology, pp 707-734. Eds LS Jefferson \& AD Cherrington. New York: Oxford University Press.

Thomas G \& Hall MN 1997 TOR signalling and control of cell growth. Current Opinion in Cell Biology 9 782-787.
Unterman TG, Oehler DT, Murphy LJ \& Lacson RG 1991 Multihormonal regulation of insulin-like growth factor-binding protein-1 in rat H4IIE hepatoma cells: the dominant role of insulin. Endocrinology 128 2693-2701.

Vlahos CJ, Matter WF, Hui KY \& Brown RF 1994 A specific inhibitor of phosphatidylinositol 3-kinase, 2-(4-morpholinyl)-8-phenyl-4H-1benzopyran-4-one (LY294002). Journal of Biological Chemistry 269 5241-5248.

Zhou XY, Shibusawa N, Naik K, Porras D, Temple K, Ou H, Kaihara K, Roe MW, Brady MJ \& Wondisford FE 2004 Insulin regulation of hepatic gluconeogenesis through phosphorylation of CREB-binding protein. Nature Medicine 10 633-637.

Received in final form 30 May 2006

Accepted 9 June 2006 